\title{
Autoimmune Hemolytic Anemia
}

\section{Otoimmün Hemolitik Anemi}

\section{Şinasi Özsoylu}

Retired Prof of Pediatrics, Hematology, Hepatology, Ankara, Turkey

Honorary fellow of American Academy of Pediatrics

Honorary member of American Pediatric Society

\section{To the Editor,}

I would like to make few comments on the Sarper and her colleagues' article entitled "Management of autoimmune hemolytic anemia in children and adolescents: a single center experience" published in the recent issue of the Journal (2011;28:198-205) [1].

First of all, Coombs test was negative two out of 13 patients with hemolytic anemia (patients 3 and 10). Although Coombs positivity may not correspond to hemolysis, because of low titer, reversals may not be expected.

As recently brought to the attention once more, the disease may differ despite of similar pathogenesis [2]. Therefore, Evans syndrome (ES) should be presented separetly then autoimmune hemolytic anemia (AIHA) as of WiskottAldrich syndrome (WAS) in which Coombs positivity may develop as of alloimmune reaction.

In addition "Patients with ES have sequentiel or spontaneous" thrombocytopenia, but it is not called ITP [3].

Although corticosteroids are the main drugs for the treatment of AIHA, it should not be used in divided doses as subtitution treatment as of surrenal insufficiency; which has been applied previously; Rather it should be given at once around 6 a.m preferentially as Megadose methylprednisolone (MDMP) [4] intravenously or orally as desribed by us which was used in parttially one of the authors' patient (30 mg/kg/day, for 3 days).

May I also remind that blood group changes may occur in autoimmune disaeses, which should be correlated with the parents blood groups.
Since the patients retrospectively reviewed, was ethic comimette approval required?

\section{References}

1. Nazan S, Suar ÇK, Emine Z, Sema Aylan G. Management of autoimmune hemolytic anemia in children and adolescents: a single center experience. Turk J Hemato 2011;28:198-205

2. Fere W, Gregory, Guttmacher AC. Genomics and the multifactorial nature of human autoimmune disaese. NEJM 2011;365:1612-23

3. Özsoylu S. Is every immune hrombocytopenia. Idıopathic thrombocytopenic purpura. Acta Paediatrica 2004;93: 1129-1130

4. Özsoylu \$̧, İrken G, Karabent A. High-dose intravenous methylprednisolone for acute childhood idiopathic thrombocytopenic purpura. Eur J Hematol 1989;42: 431-435

\section{Reply,}

In discussion we reported that false negative direct Coombs test may be found in 2-4\% of patients with autoimmune hemolytic anemia (AIHA) due to low titers of antibodies or low sensitivity of the test. We have already refered, reference 7 and 8 on the subject in our study $[1,2]$. Our patients with negative Coombs test were responsive to steroids. Özsoylu et al says that false positive Coombs test may be observed but false negative can not be observed in OIHA. He might not have such an experience. 
The aim of presenting cases with Evans syndrome and W.Aldrich syndrome in the same article was to attract attention to these cases presenting with hemolytic anemia and underlying immunodeficiency. In the last paragraphs of the abstract and discussion we said that hemolytic reactions of these cases may require other immunosupressive agents and each case must be considered indiviually before splenectomy. In the recent literature Evans syndome is presented under the title of autoimmune hemolytic anemia [3]. In Wiscott-Aldrich syndrome autoimmune hemolytic anemia develops as many other autoimmune and inflammatory complications [4], but Özsoylu says that it is an alloimmune reaction.

Özsoylu says that "Patients with ES have sequentiel or spontaneous thrombocytopenia, but it is not called ITP2". I think he wants to say "simultaneous" instead of "spontaneous". In the study we already reported that thrombocytopenic and hemolytic anemia attack may be sequential even second cytopenia may emerge over the course of ten years. When the first attack is thrombocytopenia you have to diagnose it as immune thrombocytopenic purpura because at that moment you do not know that this patient will also develop an autoimmune hemolytic anemia attack. In the recent literature Evans syndrome is described as follows [5]: "Evans syndrome (ES) is characterized by the coexistence of an autoimmune hemolytic anemia (AIHA) and immune thrombocytopenic purpura (ITP)".

Özsoylu says that corticosteroids should not be used in divided doses as subtitution treatment as of surrenal in-sufficiency; which has been applied previously. Rather it should be given at once around 6 a.m preferentially as megadose methylprednisolone (MDMP) ${ }^{3}$. In text book "Williams Hematology" "it is written that, in adults oral methylprednisolone should be used at an initial daily dose of 60-100 mg. Critically ill patients with rapid hemolysis may receive 100-200 $\mathrm{mg}$ in divided dose over the first $24 \mathrm{hr}$. ."[6]. If hemoglobin level is already stabilized at a reasonable level, I do not think megadose methylprednisolone is required. Özsoylu may prefer such high doses. In Manual of Pediatric Hematology and Oncology by Philip Lanzkowsky also, 2-6 mg/kg/day prednisolone or methyl prednisolone is recommended [7]. I do not think divided doses of corticosteroids are used always as subtitution treatment of surrenal in-sufficiency. Divided doses are also used in leukemia.

Özsoylu says that, blood group changes rarely occurs in autoimmune disaeses. So we want to attract attention to rare cases. Patient 2 was refered to us from another center after some transfusions and corticosteroid replacement and still ongoing hemolysis. We observed that blood group typing was false and transfusion with incompatible packed red cells also contributed to hemolysis.

As a conclusion, I could not find any scientific error in our article regarding Özsoylu's comments.

Nazan SARPER

Kocaeli University, School of Medicine, Department of Pediatric Hematology, Kocaeli, Turkey

\section{References}

1. Agarwal B. Autoimmune hemolytic anemia. 1998; 65: 663668

2. Collins PW, Newland AC. Treatment modalities of autoimmune blood disorders. 1992; 29: 64-74

3. Baek SW, Lee MW, Ryu HW, Lee KS, Song IC, Lee HJ, Yun HJ, Kim S, Jo DY. Clinical features and outcomes of autoimmune hemolytic anemia: A retrospective analysis of 32 cases. Korean J Hematol 2011; 46: 111-117

4. Dupuis-Girod S, Medioni J, Haddad E, Quartier P, Cavazzana-Calvo M, Le Deist F, de Saint Basile G, Delaunay J, Schwarz K, Casanova JL, Blanche S, Fischer A. Autoimmunity in Wiskott-Aldrich syndrome: Risk factors, clinical features and outcome in a single-center cohort of 55 patients. Pediatrics 2003; 111: 622-627

5. Eddou H, Helissey C, Konopacki J, Souleau B, de Revel T, Malfuson JV. Evans syndrome: Be careful of over-diagnosis. Rev Med Interne 2012; 33 (3): 155-158

6. Beutler E, Lichtman MA, Coller BS, Kipps TJ, Seligsohn U. Williams Hematology. Sixth edition 2001, McGraw-Hill Companies, New York

7. Philip Lanzkowsky. Manual of Pediatric Hematology and Oncology, Fifth edition, 2011 Academic Press, London 